\title{
Negative impact of armed conflicts on human behaviour. Specific case of old people in Bukavu town and its peripheries in Democratic Republic of Congo
}

\author{
Dennis Kingombe*
}

Address: Centre de Soutien Psychologique pour Personnes Agées, Congo

* Corresponding author

\author{
from International Society on Brain and Behaviour: 2nd International Congress on Brain and Behaviour \\ Thessaloniki, Greece. 17-20 November 2005 \\ Published: 28 February 2006 \\ Annals of General Psychiatry 2006, 5(SuppI I):SI50 doi:I0.II86/I744-859X-5-SI-SI 50
}

\section{Background}

Since the year 1996, the country particularly South-Kivu province which is border with Rwanda country have known the one of more bloody wars of the continent history, the which has done millions of victims, provoqued destructions, pillages, raps, violations so and populations movings in all directions.

This work aims to describe, nine years after, pitiful situation in the which are roting old people surviving in bukavu town and its peripheries.

\section{Materials and methods}

Tuesday and Friday of the week are the two days ordered and dedicated by urban authority to the aged persons all sexes taken together to get in town asking for charity.

In January 2005, we had programmed an investigation according to those days so that noting down near different owners and responsibles of the town shops, foodshops, and other small and medium entreprises, the old people number having passed at them. It was especially about knowing, how many were they, what had they received, in which psychological, physical and way of dressing they were presented. It were for us too interesting to knowing, in what conditions were they wellcome and served. Their respective from were of course too interesting one for us. At the last, some persons among them had been selected for one particular question.

\section{Results}

Altogether, about thirty houses functioning in Ibanda commune and practising it the aforementioned activities were regularly frequented by about 25 old people of two sexes. To be precise, on average, it were 1500 old people whom the presence were taken a census of in Ibanda commune each week.

They generally receive 1 or 2 matches representing 0.04 US $\$, 1$ bar of soap $0.1 \$$, sometimes 1 sandwich $0.1 \$$, a slice of lard or sausage $0.2 \$, 1$ small parcel of biscuit 0.1 $\$$ and 20 Congolese Franc that is to say $0.04 \$$. In concrete terms, the individually received charity represented 0.544 $\$$ each Tuesday and each Friday of the week.

They usually were traumatized, weakened, poor, plaintive and very dirty. It were disabled old persons too.

85 per cent had affirmed have been served after humiliations. The majority, that is to say 65 per cent came from town peripheries while 35 per cent dwelt the town less well-off popular quarters.

Why did they behave so? 96 per cent had replied to have not any more any support. They confessed that any of their traditional sponsors had been either killed during the war or enroled in army or had fled the areas. Congolese government has not any assistance politic to the aged persons.

\section{Discussion}

The impoverishment and the abandonment of the population are logical consequences in all long-term armed conflict like this of Democratic Republic of Congo where, the fate of old people remains so pitiful.

Unfortunately, any improvement prospect can be in short or medium terms imagined in a country where does not 
exist any national mechanism concerning the ageing because badly governance and especially the negligence of the contribution that, that "human capital" who are old people could bring to the poverty reducing around themselves in an ageing society.

Publish with Bio Med Central and every scientist can read your work free of charge

"BioMed Central will be the most significant development for disseminating the results of biomedical research in our lifetime. " Sir Paul Nurse, Cancer Research UK

Your research papers will be:

- available free of charge to the entire biomedical community

- peer reviewed and published immediately upon acceptance

- cited in PubMed and archived on PubMed Central

- yours - you keep the copyright

Submit your manuscript here:

http://www.biomedcentral.com/info/publishing_adv.asp 